\title{
Leadership, Control Mechanisms and Networks for
}

\section{Sustainable Fishing}

Ana Harumi Hayashida and José Eduardo Rolón

Causa Natura AC, Mexico City 03810, Mexico

\begin{abstract}
The purpose of this article was to analyse how fisheries governance can be improved when there is low enforcement capacity by state's institutions. Based on the theoretical arguments from the neo-institutionalism and the social capital approaches, the findings of this research point to the role of fishing cooperatives' structural organization on the attitude of individuals to comply with regulations. Using a most similar comparative method, it was found that fishers with higher scores of compliance belong to cooperatives that have an outstanding leader, control mechanisms, as well as multi-actor external networks which connect the organization with other networks and thus facilitate the access to knowledge, technology and activities related to conservation and sustainable fishing. The findings of the research coincide with other studies about the importance of leadership that enable good fishing management. This may help in the design of different strategies to address situations with low state capacity to ensure compliance and contribute to solve problems of commons, such as the one in marine fisheries.
\end{abstract}

Key words: Ostrom, Williamson, commons, fisheries governance, regulatory compliance, leadership and networks.

\section{Introduction}

It is recognized that the state plays a key role in managing fisheries. It designs and implements rules to ensure sustainable fishing. It allocates property rights in its national waters in order to limit the number of fishermen, and it is responsible for the inspection, surveillance and enforcement of fishing regulations.

Yet, over-exploitation of fisheries resources and non-compliance of fishing regulations represent a recurrent collective action dilemma in many countries, in which the individual's interest in exploiting natural resources clashes with the collective interests of conservation and sustainable use.

Illegal fishing is a public problem that contributes to the over-exploitation of Mexican fisheries resources $^{1}$. It is estimated that $45 \%$ to $90 \%$ of domestic production in Mexico comes from illegal fishing [1].

Corresponding author: Ana Harumi Hayashida, M.Sc., research field: public policy.

1 The national fisheries chart (NFC) from the National Fisheries Institute (INAPESCA) reported in 2012 that $67 \%$ of the 477 fishing species were in their maximum capacity and $17 \%$ were over-exploited.
The Mexican state has many flaws that undermine its effectiveness in ensuring regulatory compliance. As just one example, Mexico has poor surveillance capacity, with a coastline length of $11,122 \mathrm{~km}$ and more than 76,000 vessels navigating in it, but only 154 inspectors [2].

Despite the poor capacity of the Mexican state, there are cases in Mexico where fishing organizations comply with the rules and carry out good resource management. Using the case of Mexican fisheries, the paper analyses collective action and the management of common goods in weak states. It relies on a co-management perspective incorporating elements from the neo-institutionalism and the social capital theoretical approaches.

Based on the hierarchical organization approach of Williamson [3], the role of the leader in fisheries organizations is studied, as well as how leadership significantly influences the attitude of fishermen to comply with the rules for sustainable fishing. Williamson argues that a hierarchical organization reduces its transactions costs when a central member takes command decisions with no need to discuss 
them among all members of the group all the time [3]. This is visible in fishing cooperatives where the organizational structure focuses on a board of directors headed by a president who is responsible for the strategic planning of the organization.

However, unlike companies that are the subject of Williamson's analysis, the cooperatives are governed by the principle of democratic control, so a leader must always maintain the respect and approval of all members. Therefore, compliance also requires additional elements from the social capital approach. Ostrom and Ahn [4] argue that good leadership must be accompanied by citizen participation, trust, norms of reciprocity, networks and rules in accomplishing good management of the commons.

The objective of this paper aimed to contribute to the discussion of the fisheries governance. It argues that leadership and social capital are important elements for achieving compliance of rules and the adoption good management practices. To support this argument, the study was carried out in cooperatives located in the state of Quintana Roo, Mexico to analyse leadership in terms of managerial skills, as well as social capital through the study of assembly and networks.

\section{Methods}

The study used the most similar comparative method, which analyses the differences between similar cases of regulatory compliance of fisheries regulations in fishing cooperatives of Quintana Roo, Mexico. The most similar method was used to examine cases that were similar in variables that may have an impact on the dependent variable (compliance with regulations), but different in the independent variable (leadership).

\subsection{Selection of Cases}

Following this method, a first selection of cases was conducted by identifying cooperatives with similar features, such as location in a natural protected area, type of fishery (the lobster, as it is the most profitable fishery in the zone) and number of members (determined between 30 and 60 persons). These criteria were met by only five cooperatives among the 26 in Quintana Roo state. These are: (1) Isla Holbox, (2) Yalahau, (3) Isla Mujeres, (4) Espiritu Santo and (5) Banco Chinchorro.

The second phase of selection was based on experts' opinion $^{2}$ and the findings of a previous field visit ${ }^{3}$. Three cases were selected among five, and they presented the highest variation in one dimension of the independent variable- the management skills of the leader. These are Yalahau, Isla Mujeres and Espiritu Santo (Table 1).

\subsection{Data Collection}

For data collection, a survey was applied to 60 coastal fishermen, and six semi-structured interviews were conducted with main actors in cooperatives and secondary sources, such as laws, rules, specialized literature, working papers and official related reports.

\subsection{Data Analysis}

For data analysis, two different tools were used. STATA program 2012 was used to obtain descriptive data and correlation between variables. Variables were measured based on the following operationalization:

(1) Regulatory compliance was measured through five indicators: (a) respect for the ban, (b) fishing within a legal area, (c) usage of legal fishing arts, (d) release of lobsters with eggs or juvenile lobsters and (e) delivery of total catch to the cooperative.

\footnotetext{
2 The guidance of Ph.D. Amalia Gracia, professor and researcher at Colegio de la Frontera Sur, is highly appreciated as well as that of the researchers from Community and Biodiversity, AC, a civil society organization dedicated to the conservation of marine biodiversity.

3 Two field missions were conducted. The first one was conducted in August 2013 to identify differences in the study variables within a preselected group of cooperatives. For example, some dimensions of leadership and internal rules were observed, using direct observation, surveys and semi-structured interviews. Based on the findings of this first visit, case studies were selected and field instruments were improved. The second mission conducted in April 2014, focused on the study of all variables in the three selected cases.
} 
Table 1 Comparative chart among case studies.

\begin{tabular}{lllll}
\hline \multirow{2}{*}{$\begin{array}{l}\text { Cooperative } \\
\text { name }\end{array}$} & \multicolumn{3}{c}{ Similar independent variables } & Independent variable of study \\
\cline { 2 - 3 } & $\begin{array}{l}\text { Number of } \\
\text { members }\end{array}$ & $\begin{array}{l}\text { Natural protected area where the } \\
\text { cooperative is located }\end{array}$ & Fishery & Managerial skill of the president \\
\hline Yalahau & 61 & Yum Balám/Tiburón Ballena & Flake fishes, shark and lobster & Medium \\
Isla Mujeres & 35 & Isla Contoy/Isla Mujeres & Flake fishes and lobster & Medium \\
Espiritu Santo & 46 & Sian Ka'an/Arrecifes de Cozumel & Flake fishes and lobster & Very high \\
\hline
\end{tabular}

To safeguard the confidentiality of the information provided, the name of the cooperatives was changed to a fictitious one.

(2) Leadership was measured by: (a) president's ability to establish long-term goals, (b) maintenance of sound finances, (c) president's performance, (d) obedience to president's directives and (e) duration of presidency.

(3) Strength of assembly was measured by indicators, such as: (a) frequency of assembly's meetings, (b) attendance of fishermen to assembly's meetings, (c) active participation of fishermen in the meetings, (d) participation of members in the agenda setting and (e) accountability in the reports.

Unit of analysis were cooperatives, while observation units were fishermen. Each indicator could take a value of 0 or 1 . The results were summed up and weighted into an average score for each variable and cooperative. The range of $0-0.20$ represents a very low score, $0.21-0.40$ a low score, 0.41-0.60 a medium score, $0.61-0.80$ a high score and 0.81-1 a very high score.

UCINET 2014 program was used to analyse networks. Two theoretical visions of social capital were considered for this section. On one hand, relationships among members to solve problems related to fishing were studied based on Coleman's principles of cohesion [5]. On the other hand, the theoretical principles of Burt [6] about "structural holes" were considered to analyse the links of the cooperatives with other networks. The answers were synthesized in networks measures using UCINET.

\section{Results}

\subsection{Regulatory Compliance}

Among the three cooperatives studied, cooperative
Espiritu Santo obtained the highest score in regulatory compliance with 0.83 . Though the three cooperatives obtained a high score regarding the respect for the ban (an average score of 0.95 for Yalahau and Isla Mujeres, and 0.94 for Espiritu Santo), other indicators were remarkably different.

Cooperative Yalahau got an average score of 0.82 for compliance with the fishing areas limited by the polygons specified in permits or concessions. Some fishermen in cooperative Yalahau admitted to fishing in the Yalahau Lagoon, part of the Yum Balám Reserve, where fishing and the use of nets is prohibited. This restriction barely reached 0.26 in cooperative Isla Mujeres, since most of their fishermen catch lobsters outside the polygons described in their permits. Cooperative Espiritu Santo has two fishing areas-one in Cozumel Island and the other in the Espiritu Santo Bay. There is a high respect for their fishing areas in both areas, which granted an average score of 0.94 for their compliance with this rule.

Regarding the compliance with permitted fishing arts, cooperative Espiritu Santo uses only sustainable fishing arts ("jamo" and "lazo"4) at the bay. These fishing arts allow the fishermen to identify lobsters that do not meet the minimum standards and release them alive. At Cozumel Island, sustainable fishing arts are not used, as marine currents are stronger in this area, so harpooning remains the main fishing art. This cooperative reached a score of 0.84 for this indicator. The other two cooperatives still use harpoon and nets as the main fishing art, with nets being the most

\footnotetext{
${ }^{4}$ These handmade fishing arts do not harm the lobster when caught.
} 
harmful to the marine environment. None of these are permitted by Mexican regulations. Isla Mujeres had only 0.27 , while Yalahau got 0.32 for this indicator.

Closely related to the use of sustainable fishing arts is the release of lobsters with eggs and juveniles. According to the rule, the minimum catch size for lobster in the Gulf of Mexico and Caribbean Sea is $135 \mathrm{~mm}$ of abdominal length. However, unsustainable fishing arts do not permit compliance with this rule, because they harm lobsters in such a way that once they are caught, they can not be returned alive to the sea. Therefore, the score is 0 for Yalahau and just 0.10 for Isla Mujeres, while in Espiritu Santo it is 0.72 .

Delivery of total catch to the cooperative is also an indicator for this variable. According to directors' estimates, fishermen in Yalahau deliver only $50 \%$ of their catch to cooperative, in Isla Mujeres 35\% and in Espiritu Santo 70\%. The problem is worse in Isla Mujeres, because cooperative's assembly permitted fishermen to sell the fish directly to people. Only lobster is sold through cooperative, though not all of it, as a great proportion is diverted to other selling points (Table 2).

Although these three cooperatives share common features, compliance with sustainable fishing regulations is very dissimilar. What is the reason of these differences? An analysis of leadership and networks may give an answer to this question.

\subsection{Leadership}

Leadership is the condition of being a leader or the exercise of his or her functions. It is often accompanied by human attributes, such as managerial skills and the obedience of subordinates [7]. Thus, a leader has both administrative and mandate qualities.
Most of the fishing cooperatives lack of direction and planning. This is a task that lies primarily on the fishing cooperatives' presidents, but they do not always have the capacity or experience to run an organization. Some of the qualities that fishermen recognize in a good president are to maintain sound finances, to plan, to manage and implement projects that benefit the cooperative, and to commercialize the product at good price.

The president of cooperative Yalahau has held this position for nearly three years. During this period, he has not yet accomplished its main goals to build a collection centre and to find alternative markets to diversify the cooperative's sales. His ability to set clear long-term goals was assessed at 0.59. The cooperative has been carrying over debts from its sole purchaser for many years, so its finances are very poor (0.30), and the president's performance is regular (0.54) according to members of this cooperative.

The president of cooperative Isla Mujeres lacks the ability to set clear long-term goals (0.36). He has been struggling to keep the cooperative alive. His main concern is to reduce the cooperative's debts. Despite progress in debt reduction, the finances were poorly assessed (0.38), and his performance as a manager was rated in 0.63 .

Scores of cooperative Espiritu Santo's president are very high. The fishermen of this cooperative recognize a great ability in their president to set clear goals (1.00). Since he took the presidency in 1991, he established a very effective strategy to address the cooperative's debts, by establishing a commercial relationship with buyers of live lobsters, which brings higher returns to the cooperative. At the same time, he convinced members to adopt sustainable fishing methods.

Table 2 Regulatory compliance (average scores).

\begin{tabular}{|c|c|c|c|c|c|c|}
\hline Cooperative & $\begin{array}{l}\text { Respect for the } \\
\text { ban }\end{array}$ & $\begin{array}{l}\text { Respect for } \\
\text { fishing areas }\end{array}$ & $\begin{array}{l}\text { Use of permitted } \\
\text { fishing arts }\end{array}$ & $\begin{array}{l}\text { Release of lobsters } \\
\text { (with eggs or juvenile) }\end{array}$ & $\begin{array}{l}\text { Delivery of total } \\
\text { catch to cooperative }\end{array}$ & $\begin{array}{l}\text { Average of } \\
\text { compliance }\end{array}$ \\
\hline Yalahau & 0.95 & 0.82 & 0.32 & 0.00 & 0.50 & 0.52 \\
\hline Isla Mujeres & 0.95 & 0.26 & 0.27 & 0.10 & 0.35 & 0.39 \\
\hline Espiritu Santo & 0.94 & 0.94 & 0.84 & 0.72 & 0.70 & 0.83 \\
\hline
\end{tabular}

Source: own elaboration based on surveys ( $n=22$ for Yalahau; $n=19$ for Isla Mujeres; $n=18$ for Espiritu Santo). 
Hence, his performance has been well evaluated (0.93), and he has been re-elected several times (Table 3).

It is notable that cooperative Espiritu Santo is the cooperative with the highest rate of compliance with the rules (0.83), and has also the strongest leadership (0.90). The slope in Fig. 1 shows a positive relationship between compliance and leadership $\left(R^{2}=\right.$ $0.30 ; P>|t|=0.000, n=59$ ).

\subsection{Strength of Assembly}

Assembly is the highest authority of the cooperative and is integrated by all members. However, private interests of board's president sometimes prevail above assembly's interest. Thus, there are cases of authoritarian governments, corruption, embezzlement and predominance of private interests over public ones.
For a leader to conduct according to public interests, assembly must operate as a superior decision-making organ that controls directives' behaviour.

The work of cooperative Espiritu Santo's president has been important in modifying the behaviour of fishermen. However, this has been possible because assembly, integrated by all members, supports these actions. Ordinary assembly meetings are carried out three times a year, but there are also monthly meetings, which increase the opportunity of the board to meet with fishermen to discuss projects which they seek to promote. There is a high attendance to these meetings (1.00), and a regular participation of members in meeting's discussions (0.55). According to the results, the members feel well informed based on technical and financial reports (1.00) (Table 4).

Table 3 Leadership (average scores).

\begin{tabular}{lllllll}
\hline Cooperative & $\begin{array}{l}\text { Setting long-term } \\
\text { goals }\end{array}$ & Sound finances & $\begin{array}{l}\text { Performance of } \\
\text { president }\end{array}$ & $\begin{array}{l}\text { Obedience to } \\
\text { president }\end{array}$ & $\begin{array}{l}\text { Duration of } \\
\text { presidency }\end{array}$ & $\begin{array}{l}\text { Average of } \\
\text { leadership }\end{array}$ \\
\hline Yalahau & 0.59 & 0.30 & 0.54 & 0.80 & 0.00 & 0.44 \\
Isla Mujeres & 0.36 & 0.38 & 0.63 & 0.89 & 0.00 & 0.45 \\
Espiritu Santo & 1.00 & 0.63 & 0.93 & 0.97 & 1.00 & 0.90 \\
\hline
\end{tabular}

Source: own elaboration based on surveys ( $n=22$ for Yalahau; $n=19$ for Isla Mujeres; $n=18$ for Espiritu Santo).

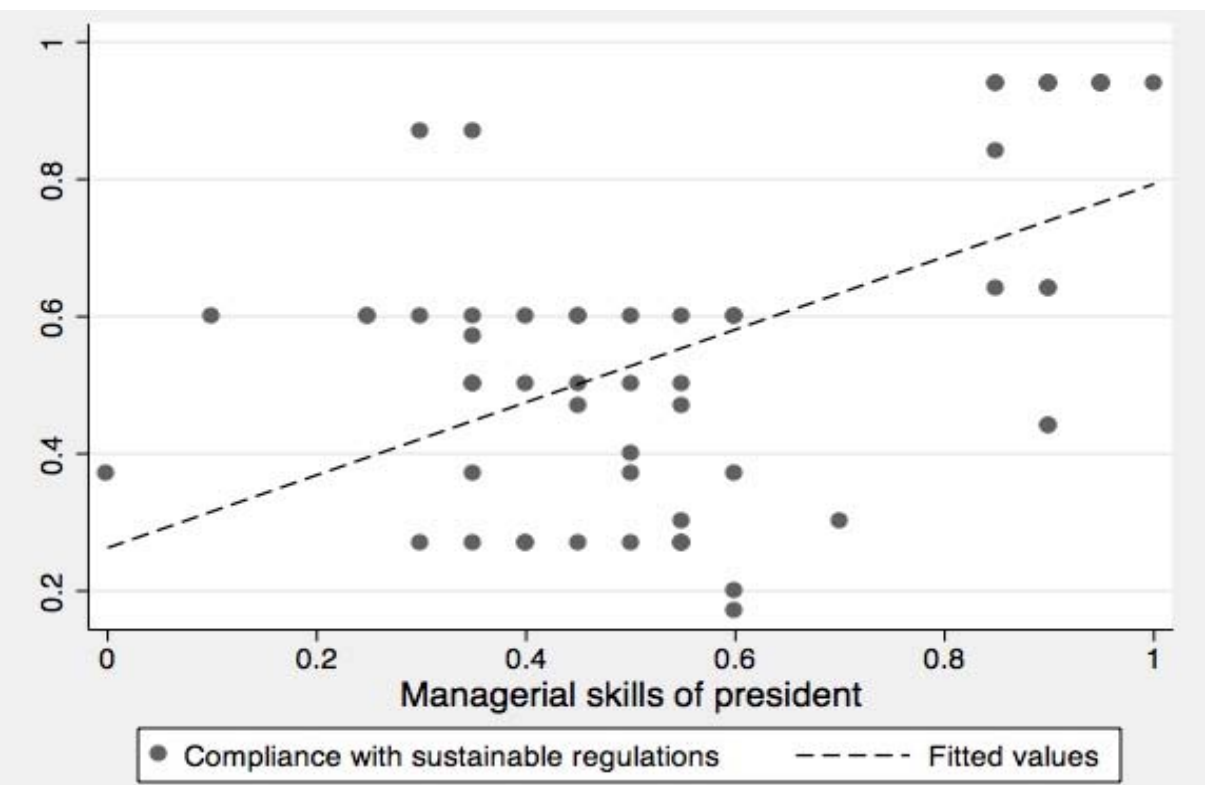

$$
C=0.26+0.53 L+\varepsilon
$$

Fig. 1 Scatter plot and regression line of regulatory compliance and leadership.

Source: own elaboration based on surveys.

The scatter plot shows the values of two variables in a data set. These data are shown as a set of points; each one represents the value of the independent variable at the horizontal axis and the value of the dependent variable at the vertical axis for one observation. 
Table 4 Strength of assembly (average scores).

\begin{tabular}{lllllll}
\hline Cooperative & $\begin{array}{l}\text { Frequency of } \\
\text { assembly's } \\
\text { meetings }\end{array}$ & $\begin{array}{l}\text { Assistance to } \\
\text { ordinary } \\
\text { assemblies }\end{array}$ & $\begin{array}{l}\text { Active participation } \\
\text { of fishermen in } \\
\text { assemblies }\end{array}$ & $\begin{array}{l}\text { Participation of } \\
\text { fishermen in } \\
\text { agenda setting }\end{array}$ & $\begin{array}{l}\text { Accountability in } \\
\text { reports }\end{array}$ & $\begin{array}{l}\text { Average of } \\
\text { assembly's } \\
\text { strength }\end{array}$ \\
\hline Yalahau & 0.00 & 0.88 & 0.59 & 0.53 & 0.00 & 0.40 \\
Isla Mujeres & 0.00 & 0.98 & 0.55 & 0.61 & 1.00 & 0.63 \\
Espiritu Santo & 1.00 & 1.00 & 0.55 & 0.50 & 1.00 & 0.81 \\
\hline
\end{tabular}

Source: self-elaboration based on surveys ( $n=22$ for Yalahau; $n=19$ for Isla Mujeres; $n=18$ for Espiritu Santo).

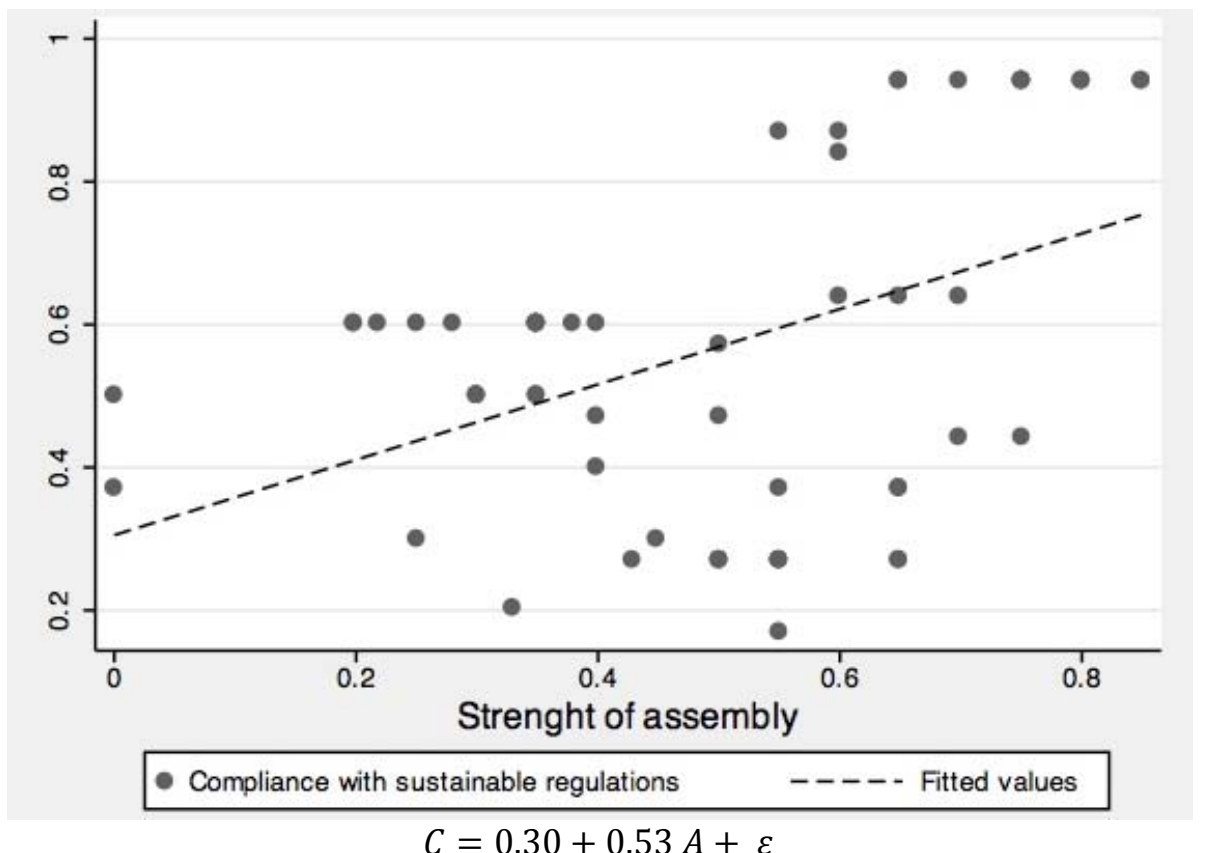

Fig. 2 Scatter plot and regression line of regulatory compliance and assembly's strength.

Source: own elaboration based on surveys.

The cooperative Isla Mujeres was the first cooperative established in Quintana Roo state. However, the adoption of new members is frozen since 1981. This strategy was implemented by the cooperative to protect their interests against external influences. However, their members are ageing without support of young people. The attendance of members to meetings is high (0.98), however their active participation during the meetings is poor (0.55).

Strength of the assembly of cooperative Yalahau is weak (0.4). The members of this cooperative gather twice a year. There is a very high attendance of members (0.88), but a regular participation in debates (0.59). Accountability of finance statements is very low (0). According to fishermen, board's president position has been used to satisfy particular interests. There have been cases of corruption and embezzlement, with no penalties for those who have misbehaved.

The cooperative Espiritu Santo holds the highest values. Fig. 2 shows a positive relationship between compliance and assembly's strength. This relationship is also statistically significant $\left(R^{2}=0.20 ; P>|t|=\right.$ $0.000, n=59$ ).

Summing up, the slopes of the lines in Figs. 1 and 2 show a positive relationship between compliance and leadership, and between compliance and strength of the assembly. To analyse the causal link between compliance and the two variables, a 2-stage least squares (2SLS) model was developed, using assembly as an instrumental variable of leadership. This is consistent with qualitative findings, which reveal that assembly not necessarily influences compliance by itself. In cooperative Isla Mujeres, it was found a 
Table 5 First stage regression analysis.

\begin{tabular}{llll}
\hline Leadership & Coefficient & Standard error & $P>|t|$ \\
\hline Strength of assembly & 0.89 & 0.11 & 0.000 \\
Constant & 0.13 & 0.06 & 0.030 \\
$R^{2}=0.53$ & & & Prob $>F=0.0000$ \\
\hline
\end{tabular}

Source: own elaboration based on surveys.

Table 6 Second stage regression analysis.

\begin{tabular}{llll}
\hline Compliance & Coefficient & Standard error & $P>|t|$ \\
\hline Leadership & 0.59 & 0.14 & 0.000 \\
Constant & 0.23 & 0.09 & 0.015 \\
$R^{2}=0.29$ & & & Prob $>F=0.0002$ \\
\hline
\end{tabular}

Source: own elaboration based on surveys.

deliberative assembly with power to control the board, but with no influence in fishermen's behaviour.

The 2SLS analysis indicates that relation between assembly and leadership is positive and significant (Table 5). Likewise, an increment of one unit in leadership leads to an increment of 0.59 in regulatory compliance (Table 6).

\subsection{Networks}

\subsubsection{Internal Networks}

Coleman states that relationships between individuals are a kind of social capital that facilitates collective action. This virtue increases when the links between nodes or actors are close (cohesion). This means that a greater number of connections within a network help its members to overcome self-interest and act for the benefit of the community [5]. To analyse the levels of cohesion in the three cooperatives, fishermen were asked the person(s) who they rely upon when they need three questions about: (1) new equipment (motor or fishing arts); (2) guidance in their work (where or how to fish); (3) to solve an economic difficulty (related to the job), and if this person is a member of the cooperative (manager of the cooperative, member of the general assembly, assistant) or if it is an external actor.

Figs. 3-5 show the networks of Yalahau, Isla Mujeres and Espiritu Santo. It showed that cooperative Yalahau and Espiritu Santo have a high degree of centralization, which is noted mainly in the concentration of the president's power. Cooperative Yalahau centralization is of $82.20 \%$ and Espiritu Santo is of $83.25 \%$ (Table 7). This means that president is the first person, to whom fishermen of these cooperatives turn to solve a problem related to equipment, information and finances, with other members of the board (treasurer, secretary and president of surveillance) in second place.

In contrast, cooperative Isla Mujeres has a centralization of $26 \%$. It is a dispersed network, where disconnected nodes can be appreciated as in the case of Martin, William and Andres Be (Fig. 4). These fishermen are members of the cooperative, but they do not receive support from it, so they rely on their family networks. This network also shows a large number of external actors (12 actors) as sources of support ${ }^{5}$. This means that cooperative has a weak internal capacity to support its members.

Table 7 shows that the cooperative Espiritu Santo has the highest centralization (83.25\%), but it is also the one with the highest density (4.5\%) or degree of cohesion. Cooperative Isla Mujeres holds the lowest centralization (26\%) and it is also the cooperative with less cohesion with a density of 3.2\%. Finally, Cooperative Yalahau holds a high centralization (82.20\%) and a density of $4.1 \%$.

\footnotetext{
${ }^{5}$ Fishermen of cooperative Yalahau mentioned four external actors, and Espiritu Santo mentioned two.
} 


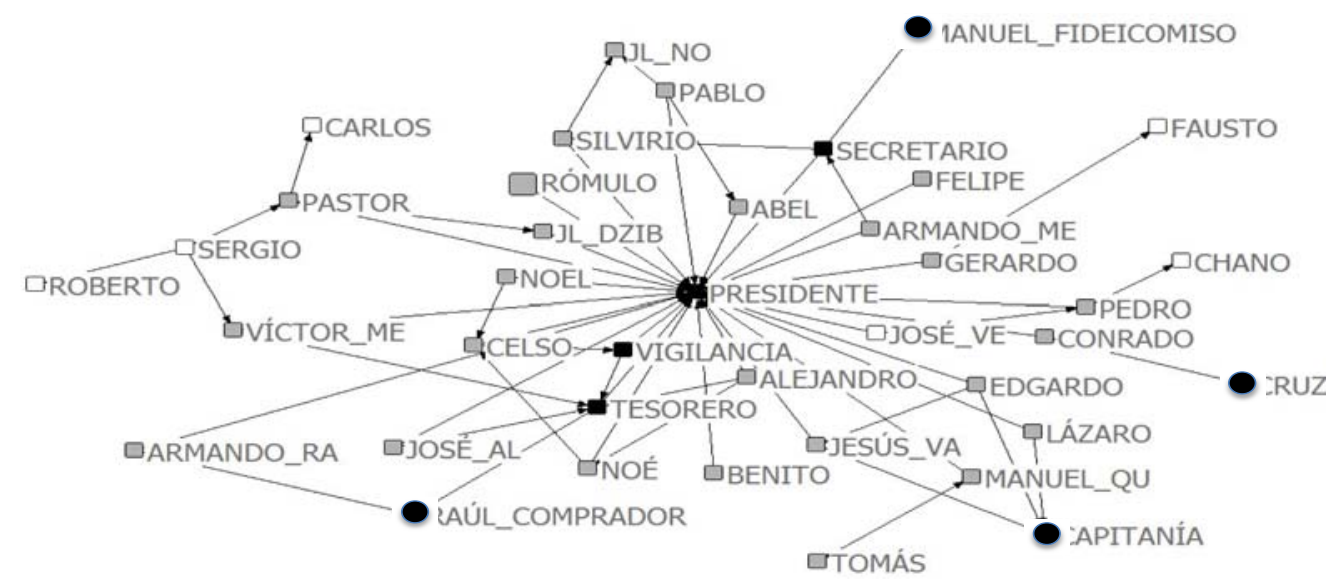

Fig. 3 Network of cooperative Yalahau.

Source: own elaboration based on surveys.

Black square: directive; grey square: fisherman member of assembly; white square: fisherman not member of the assembly; black circle: external actor.

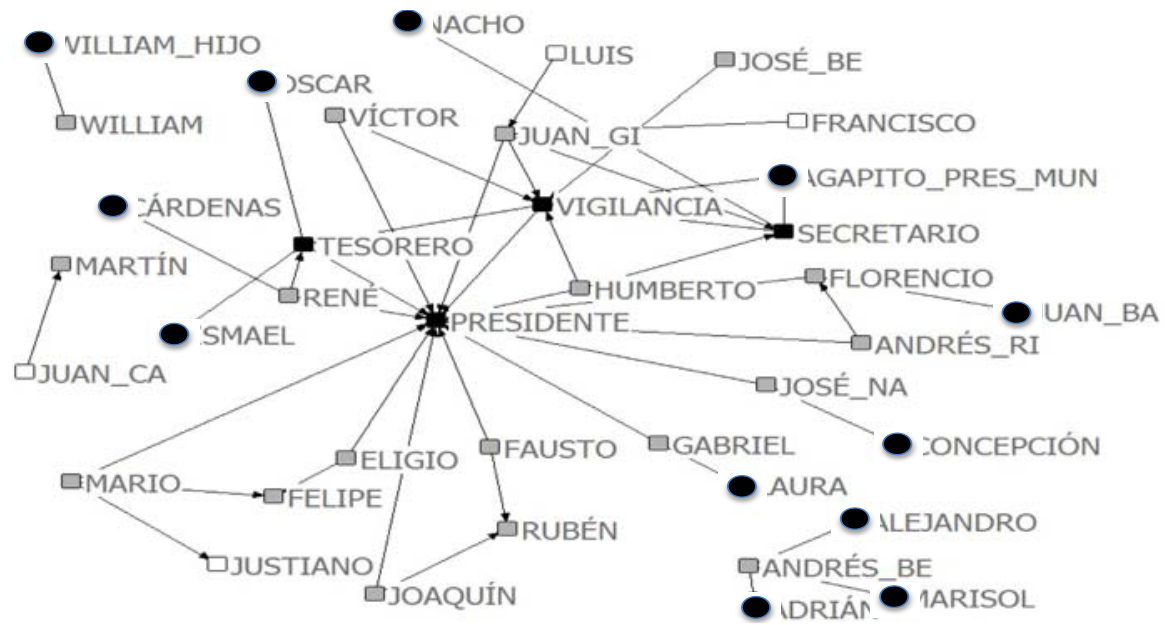

Fig. 4 Network of cooperative Isla Mujeres.

Source: own elaboration based on surveys.

Black square: directive; grey square: fisherman member of assembly; white square: fisherman not member of the assembly; black circle: external actor.

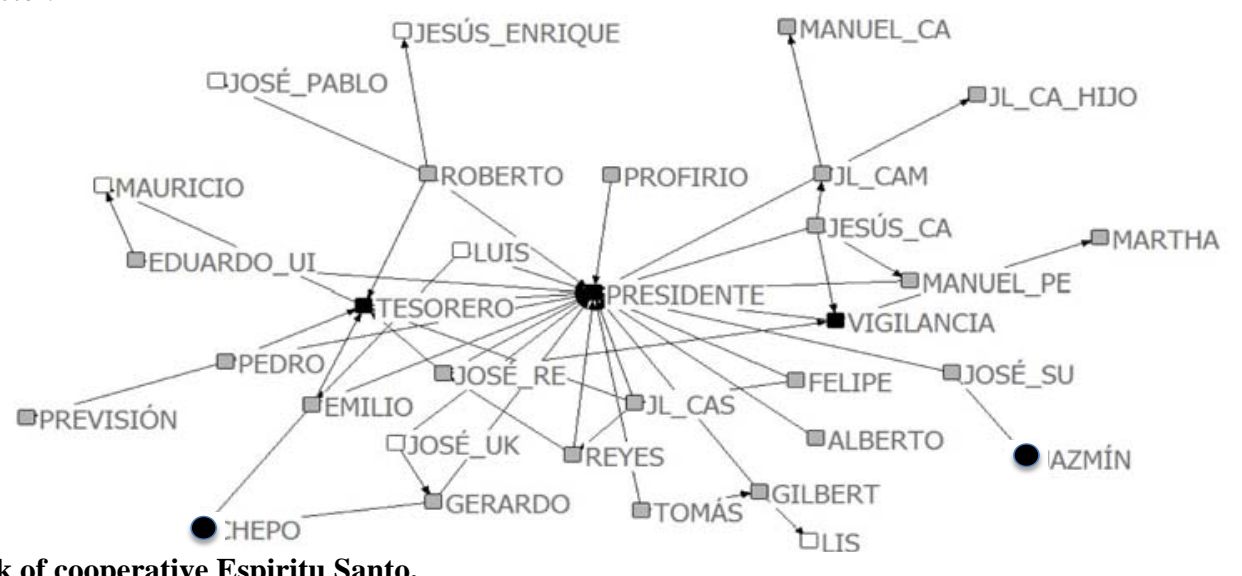

Fig. 5 Network of cooperative Espiritu Santo.

Source: own elaboration based on surveys.

Black square: directive; grey square: fisherman member of assembly; white square: fisherman not member of the assembly; black circle: external actor. 
Table 7 Structural characteristics of Espiritu Santo, Isla Mujeres and Yalahau networks.

\begin{tabular}{llll}
\hline Measures & Espiritu Santo & Isla Mujeres & Yalahau \\
\hline Number of nodes & 33 & 38 & 35 \\
Density $^{1}$ & $4.5 \%$ & $3.2 \%$ & $4.1 \%$ \\
Centralization & $83.25 \%$ & $26.00 \%$ & $82.20 \%$ \\
(Indegree) & & & \\
\hline
\end{tabular}

Source: own elaboration based on surveys.

${ }^{1}$ Density is calculated by dividing the number of relations between the possible ones in a network and multiplied by 100.

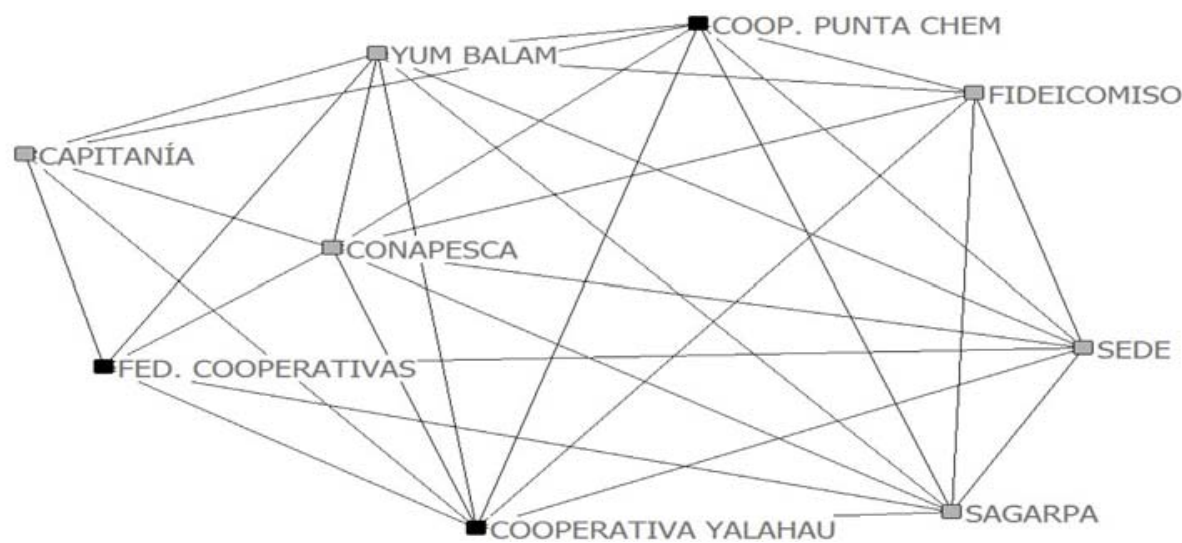

Fig. 6 Links of cooperative Yalahau president.

Source: own elaboration based on surveys.

Black square: cooperative; grey square: governmental institute. Number of nodes was nine.

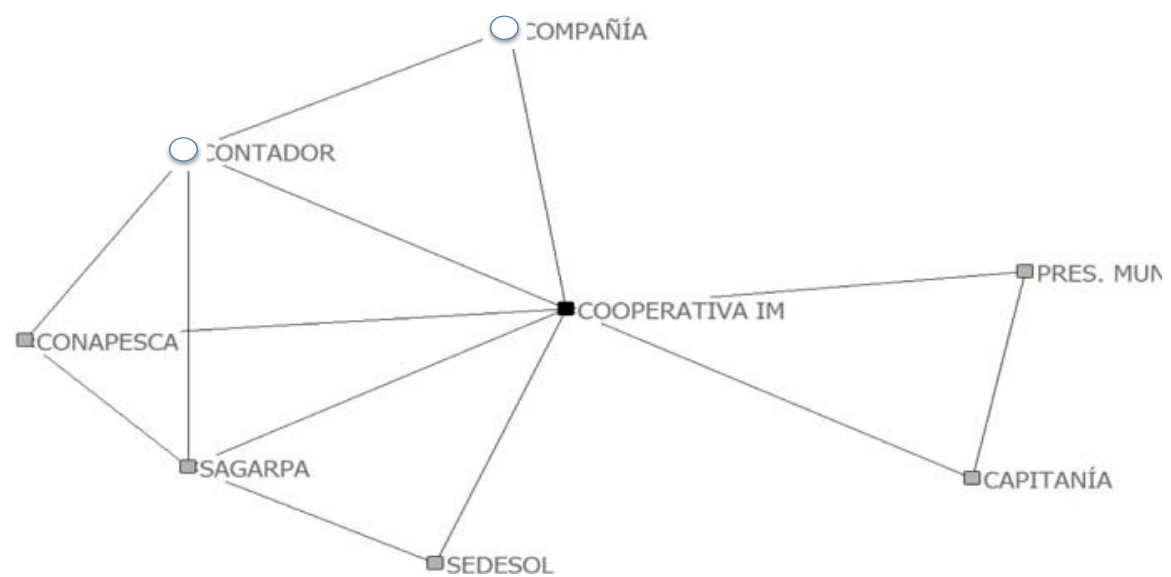

Fig. 7 Links of cooperative Isla Mujeres.

Source: own elaboration based on surveys.

Black square: cooperative; grey square: governmental institute; white circle: private sector. Number of nodes was eight.

This analysis shows that fishing cooperatives have high levels of centralization when solving routine issues. Following Williamson's theory [3] based on the efficiency of hierarchical organizational structures, it is found that these structures can be very efficient when a person with exceptional abilities is in charge of the organization.

\subsubsection{External Networks}

External links are also an important source of social capital. Information, technology and physical and monetary resources may permeate into a certain network through the so-called "structural holes". To analyse cooperatives' networks, the presidents were asked about the number and type of actors that they relate while doing their job.

Figs. 6-8 represent actors (nodes) linked with the cooperative through board's president. It showed that there are apparent differences in the number and type 


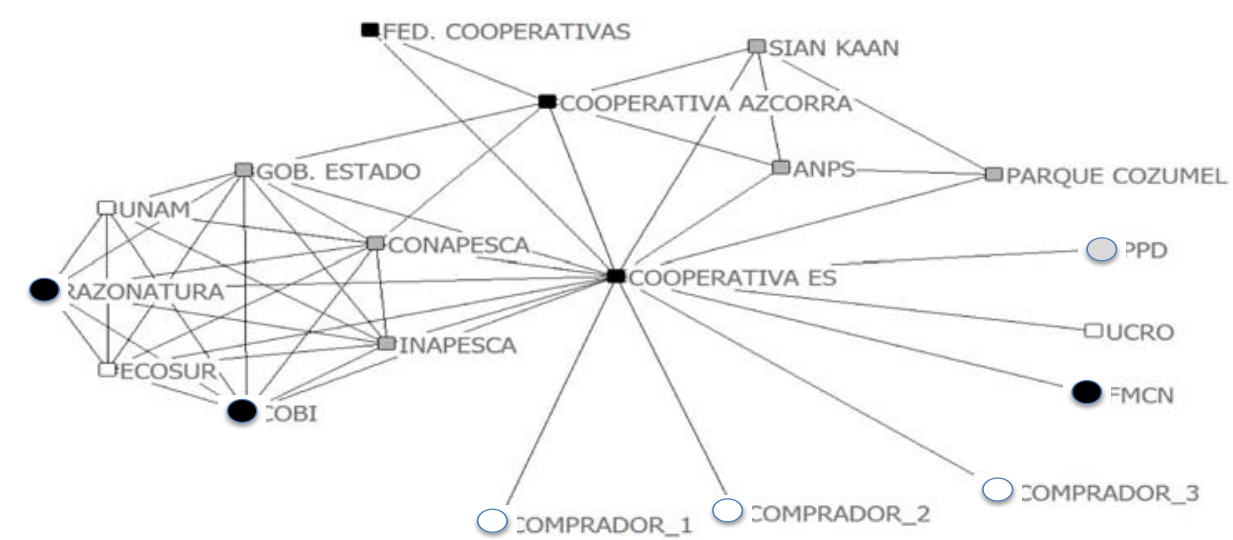

Fig. 8 Links of Cooperative Espiritu Santo president.

Source: own elaboration based on surveys.

Black square: cooperative; grey square: governmental institute; white square: academia; black circle: NGO; grey circle: international organism; white circle: private sector. Number of nodes was 19.

of relations that the cooperatives have with external actors or organizations. Yalahau cooperative is formed in a very closed network (Fig. 6). Almost all actors of this network (from the president's perspective) know each other. This formation has brought benefits to the cooperative Yalahau in easily carrying out governmental procedures. However, the diversity of its connections is limited. This cooperative does not interact with other organizations, such as non-governmental organizations (NGOs) and academia.

Cooperative Isla Mujeres has poor relationship capital, both in numbers and diversity. The cooperative interacts little with other actors or organizations. The accountant performs tasks that are supposed to be carried out by the president, such as processing permits and marketing. Thus, the president rarely connects with governmental officials, except when ordinary assemblies meetings take place. In this network, the president appears as a central actor, who appears as the only connection (from his perspective) with some nodes, such as the mayor and the harbour's captain (Fig. 7).

Cooperative Espiritu Santo is clearly associated with a great diversity of actors (Fig. 8). This has brought advantages to the cooperative, such as becoming involved in various projects, which brings in new knowledge, infrastructure and other resources related to conservation and the sustainable management of resources. It is a network with structural holes, where the president is clearly a bridge between different networks. If we remove the node of the president, some nodes in the graph would be lost. This means that the president has an intermediary role that places him in a highly strategic position, allowing the president to interact with other actors with some authority for the cooperative's benefit.

\section{Discussion}

The role of the state in the management of common goods is essential. With regard to fishery resources, it is responsible for the design and implementation of regulations in accordance with the minimum environmental standards that ensure sustainability of resources. It is also responsible for issuing permits and concessions that limit the number of fishermen in the sea. However, its capacity to monitor and enforce fishing regulations is insufficient.

Co-management is an alternative that involves the users of the resources in tasks that have traditionally been responsibility of the state, such as surveillance, design of rules and sanctions. Several studies show that these forms of self-management have been effective in achieving collaboration. This research is consistent with self-management approaches, but differs from Ostrom's view in privileging dense and 
horizontal structures over vertical ones to solve collective action problems [8]. The findings of this research show that fishing cooperatives in Mexico operate vertically and within centralized internal networks. The president and other members of the board are key players in solving problems faced by fishermen on a day to day basis, such as the procurement of equipment, information and financial resources. Strategic planning of projects and activities are in hands of a few actors within a cooperative.

Thus, support for a given leadership is a cornerstone in the cooperative's evolution and affects its member's behaviour. The relationship between compliance and leadership is statistically significant. Gutiérrez et al. [9] also agree with the importance of a leader possessing entrepreneurial and managerial skills, who is highly motivated and with legitimacy in their community, in the enforcement of rules. Yet, in the analysis of McCay et al. [10], it was found that some cooperatives in the Mexican Pacific are more likely to rotate positions and generate counterweights to the president and disperse leadership widely within the group. This opens a debate about different types of internal structures and the conditions in which they emerged.

Finally, external networks are determinant in achieving compliance. The richness of relationships in cooperative Espiritu Santo points to a form of environmental governance, where resource management is shared between several actors from government, academia and civil society. A strong intermediation by the president, as a connector between networks, is also observed.

\section{Conclusions}

This study demonstrates that strong leadership is a key factor in strengthening compliance with sustainability rules. In this respect, public policies must support actions aiming to strengthen the capacity of leaders in fishing organizations. This means also encouraging managerial skills in the handling of finances, marketing and value-added production, as well as other business skills.

Resources allocated to improve compliance should promote greater knowledge among fishing leaders and other members of fishing cooperatives, of both the economic and ecological issues entailed in respect for the rules while promoting sustainable fishing.

Developing strategies to encourage the formation of multiple stakeholders must be also studied. Governance of commons requires the active participation of both public and private actors in managing resources. Encouraging networking among diverse actors in fishing organizations enhances the vision of fishermen towards a sustainable management of fisheries.

One consideration that must be pointed out from this conclusion is that successful co-management as stated in this paper could be highly dependent upon a single leader. This includes having managerial skills and established networks with external actors deposited in one person. Collaboration with hierarchical structures is possible, but can be limited over the long term, if new leaders are not developed in order to keep the social capital strong within an organization.

Further analysis should examine how rotation and balance of power may enhance strong leaderships and sound administrations leading to good governance. Experiences from other case studies with different leadership arrangements can be helpful in this task. This may expand our knowledge about the relationship between leadership, democratic culture and the success of collective organizations in decision-making spaces, such as the common fisheries.

\section{Acknowledgments}

This research could not have been possible without the support and guidance of Ph.D. Gisela Zaremberg, Ph.D. Rodrigo Salazar, Ph.D. Amalia Gracia and Ph.D. Luis Bourillón. Their contributions are sincerely appreciated and gratefully acknowledged. 


\section{References}

[1] Mexican Institute for Competitiveness (IMCO). 2013. Illegality of Fisheries in Mexico: A Barrier to Competitiveness. (in Spanish)

[2] National Commission of Aquaculture and Fishing (CONAPESCA). 2013. Open Data of CONAPESCA. (in Spanish)

[3] Williamson, O. E. 1975. Markets and Hierarchies, Analysis and Antitrust Implications: A Study in the Economics of Internal Organizations. New York: Free Press.

[4] Ostrom, E., and Ahn, T. K. 2003. "A Social Science Perspective on Social Capital: Social Capital and Collective Action.” Mexican Magazine of Sociology January-March, No. 1: 155-233. (in Spanish)

[5] Coleman, J. S. 1988. "Social Capital and Human Capital Building.” Zona Abierta Magazine 2001, No. 94/95. (in
Spanish)

[6] Burt, R. S. "Structural Holes Versus Network Closure as Social Capital.” In Social Capital: Theory and Research, edited by Lin, N., Cook, N., and Burt, R. S. New York: Aldine de Gruyter, 31-56.

[7] Borja, R. 1997. Encyclopedia of Politics. Mexico: Fondo de Cultura Economica. (in Spanish)

[8] Ostrom, E. 2011. Governing the Commons: The Evolution of Institutions for Collective Action. Cambridge, UK: Cambridge University Press.

[9] Gutiérrez, N. L., Hilborn, R., and Defeo, O. 2011. "Leadership, Social Capital and Incentives to Promote Succesful Fisheries.” Nature 470: 386-9.

[10] McCay, B. J., Micheli, F., Ponce-Díaz, G., Murray, G., Shester, G., Ramirez-Sanchez, S., and Weisman, W. 2013. "Cooperatives, Concessions and Co-management on the Pacific Coast of Mexico.” Marine Policy 44: 49-59. 